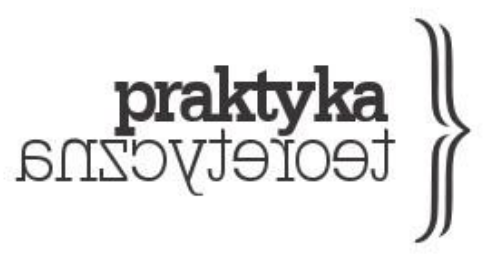

ISSN 2081-8130

DOI: $10.14746 /$ prt.2018.1.8 www.praktykateoretyczna.pl

\title{
INSTITUTING THE COMMON IN ARTISTIC CIRCULATION: FROM ENTREPRENEURSHIP OF THE SELF TO ENTREPRENEURSHIP OF THE MULTITUDE
}

\author{
KUBA SZREDER
}

\begin{abstract}
In this paper I trace the contradictions embedded in global artistic circulation, which is dialectically analysed as a nexus of exploitation and a site where the commons can be instituted. To enable this argument, I synthesise the methodologies of dialectical materialism, the sociology of art and action research, supplementing a theoretical overview of systemic pressures with a keen observation of the social practices that emerge in critical response to it. Basing my analysis on empirical evidence, I examine social conflicts, triggered by the extracting value from the distributed labour of artistic networks, as political opportunities to be seized by progressive art workers. Thus, I propose a new perspective on current processes of incorporating contemporary art into the late-capitalist cycles of accumulation and modes of establishing and reproducing social distinctions. Instead of mourning for presumably lost but still positively valorised - artistic autonomy, I argue for a revamping of the apparatuses regulating artistic circulation for the sake of the labouring multitudes.
\end{abstract}

Keywords: artistic circulation, social conflict, the common, self-entrepreneurship, structural opportunism, art workers. 
When analysing artistic circulation, one is faced with a paradox. Even though the globalized system is grounded in social cooperation its effects are privatized, as every producer moves between projects as an atomized individual. On the one hand, most cultural producers face precarity, exclusion and poverty. On the other, some of them enjoy unprecedented levels of freedom and mobility, being able to engage in meaningful undertakings with like-minded people in distributed systems without any need for centralized coordination. At first glance, this may seem like the general intellect in action, an epitome of self-organization based on principles of personal autonomy and free exchange. But, as I shall argue, this is only a semblance of the common (Hardt and Negri 2009, 175-184).

My ambition here is to move beyond mere critique. The argument is that artistic circulation can become an institution of the common as a result of the social struggles waged by art workers, who institute the common owing to productive withdrawals - art strikes, occupations, boycotts. Instead of predefining what institutions of the common are (see Hardt and Negri 2017, 104), I will rather ask what they do, looking for instances of commoning in social struggles provoked by the inequality and expropriation inherent to this circulation. To identify where, how and if the common can be instituted, following in Marx's footsteps, I will delve into the abode of networked, cultural production to identify the conflicts that erupt at the nexuses where social labour is extracted as privatized capitals. I will argue that the resistance provoked in the extraction process is socially productive, and that this prompts the circulation of art to become a form of the common by socializing the means and gains of distributed, social productivity underpinning the art system. Follow the conflict, one might quip, and gain a more acute understanding of what looms at the end of it, thus anchoring theory in social praxis.

\section{From false oppositions to the dialectics of circulation}

So, my aim here is dialectically to trace the oppositions, tensions and conflicts underpinning the circulation of contemporary art. Just as for the metropolis is, for Antonio Negri and Michael Hardt, a factory of the multitude (Hardt and Negri 2009, 249-263), a site where the common emerges and where the extraction of value unfolds, networks and projects are, for me, apparatuses that both facilitate social cooperation and enable the extraction of value from the many to the few (Szreder 2016; 2015a).

Some words are needed though to introduce a dialectical method of understanding this subject. I do not only account for the oppositions and ambivalences of networked-modes of production, but also consider them as sites of social struggles and potential becoming of 
the institutions of the common. In order to dialectically understand conflicts that erupt at different nodes of global artistic circulation, I not only introduce but also modify several theoretical concepts, the attempt being to grasp the complex dynamics of this social universe, in which the topsy-turvy economy of autonomous art (in itself based on economic denial) is overdetermined by late capitalism, with its extended modes of value extraction. Here I conduct a thought experiment. Following on from the basic premises of dialectic materialism, I use the theoretical model of conflict between capital and labour as an intellectual framework to identify and analyse the frictions specific to artistic circulation. Obviously, this model needs adjustments if it is to explain the social universe, in which people frequently work for no money but instead for reputation or for the "love of art," in which access to accumulated social production is not mediated by economic capital, but by social connections, in which those who often feel most exploited are those who are not employed but rather used as a mere human resource. To understand such peculiarities, I introduce the sociological concept of capitals (in plural), adjusting the Marxist notion of capital to grasp symbolic and social hierarchies that are not directly economic in nature. Another potential confusion stems from the dialectical understanding of the entrepreneurship mobilized in networked operations. As I will argue, the very model of entrepreneurship of the self should be considered not only as a social and ideological apparatus, but also as a site of conflict. As suggested in the title, in the process of political mobilization entrepreneurs of the self can become entrepreneurs of the multitude, instituting the commons by challenging the systemic pressures that, if left unchecked, atomize them as competitive opportunists.

To trace this dialectic, one needs to move beyond false oppositions between institutional inside and outside, flatness and hierarchy, agency and co-optation through countercultural demands. In accordance with the opposition between the institutional outside and inside, artists and theorists such as Andrea Fraser and Isabelle Graw work to eradicate the possibility of instituting alternatives to existing institutional configurations, to the art market and corporate museums (Graw 2006; Fraser 2006). In the context of such simplistic oppositions, Gerald Raunig introduces the notion of non-dialectical resistance (Raunig 2009). As he argues, instituting exodus or instituting the commons simultaneously works to undermine ossified institutions as it enacts alternative institutional forms. Hardt and Negri recently reformulated this argument in their Assembly (Hardt and Negri 2017), but it is also is a recurring topic in debates about artistic self-organization, as flocks of mock-, alter-, pataor monster-institutions frequent chapters on the social theory of contemporary art (Carrillo 2017; Baravalle 2018; Sholette 2011; Universidad Nomada 2009). In these emergent formations, as I argue in the final sections of this text, one can trace nascent forms of 
the common, forms that rearticulate the dynamic of circulation beyond the false opposition of inside-outside.

Another false opposition is that proposed by Pascal Gielen, who contrasts the world of flat networks - understood by him as sites of anomy, chaotic accumulation and widespread competition between atomized producers - with the more vertically oriented civic institutions of Western modernity, which were at the very least able to uphold the values of civil society by opposing the subsumption of all spheres of life to capitalist logic (Gielen 2013). Theoreticians like Raunig and Isabel Lorey quite rightly point out that not only were the institutions of bourgeois society not so civic to be worth the nostalgia of mourning, but that in the horizontal networks specific to social movements, new forms of selfgovernment emerge, ones that are more democratic than those of bourgeois society (Raunig 2013b; Lorey 2013). In this sense, contrasting disrupted value systems of flat networks with the civic verticality of "proper" institutions is just empty rhetoric. This issue requires a more dialectical approach like the one Paolo Virno elaborates in his discussion of the contemporary forms of cynicism specific to the flexible social structures of late capitalism (Virno 2004, 84-86). As everyone in these societies is mobile and exposed to many value systems simultaneously, each of these systems is considered arbitrary. On the one hand, flexible producers are thereby tempted to undermine the laws of equivalent exchange, considering every social situation an occasion for self-promotion [the aspect on which Gielen focuses (Gielen 2009, 36-37)]. But, on the other, the shared perception of the arbitrariness of value systems (which are indeed arbitrary and veil relations of power) might be used to activate the general intellect to establish better social systems, prompting an exodus a productive withdrawal - from the current ones.

\section{Between co-optation and dissent}

The debate about the possibility of enacting alternative, non-hierarchical institutional systems directly or indirectly touches upon the legacy of countercultural dissent, in particular of the workers and students' upheavals of the 1960s and 1970s. When Luc Boltanski and Eve Chiapello suggested that the new spirit of capitalism co-opts what they call the "artistic critique of capitalism," which, in contrast to a more egalitarian one, promotes such bohemian values as personal freedom, self-realization and creativity (Boltanski and Chiapello 2005, 97), they provoked direct rebukes and polemics from many, including Maurizio Lazzarato (Lazzarato 2011, 2009). Concerning the example of dissenting creative workers, Lazzarato 
pointed out that the demands for freedom and self-governance are complementary and not opposed to egalitarian forms of critique.

At a deeper level, this discussion refers to the status of flexibility, mobility, selfgovernance and creativity as they are embedded in the contemporary systems of organizing creative labour. The resounding question is whether they are directly subsumed in the new cycles of capitalist accumulation or rather evoke demands and desires of living labour, which are captured by capitalist machines at later stages. But all sides of the debates are in agreement that capitalism has transformed itself in recent decades. In their treatise Boltanski and Chiapello dissect this evolution. Analysing discourses of new managerialism from the 1970s and 1980s, they provide evidence of how capitalist management has responded to demands for freer and less dull work places, appeasing artistic critique by implementing some of its mechanisms while disarming its potential (Boltanski and Chiapello 2005, 199-202). As a result a new spirit of capitalism emerged, rearranging organizational mechanisms and value systems around the notions of projects, networks, connections, flexibility, mobility and creativity (Boltanski and Chiapello 2005, 4-41).

By contrast, post-operaists like Lazzarato focus on social movements, evidencing their potentia, as well as on locating a power of dissent and agency in immaterial labourers, or precarious workers, dubbed the rebellious multitudes. The argument runs as follows: capitalism has had to change to placate social dissent, which in the 1960s and 1970s was powerful enough to thwart at least some of capitalism's mechanisms. The transformation was not prompted by managers but by workers' demands, and the new forms of organizing labour are nothing but empty shells. Not only do demands for freer and self-governed life remain unfulfilled, but they still politically charged, able to prompt the social development of more democratic and non-hierarchical social assemblies. Here I share Virno's more dialectical understanding of this situation, according to which flexible modes of production can either prompt negative sentiments like cynicism, fear, opportunism, or else be articulated progressively as a socialized, general intellect.

These debates riff on another, even more fundamental discussion that refers back to the process of extracting capital in cognitive capitalism, the post-operaist position on which was meticulously reconstructed by Mikołaj Ratajczak, and additionally applied by him to the realm of artistic labour (Ratajczak 2014, 2015). The question is whether social production of value is an autonomous process that is organized within the multitude and only secondarily captured by capitalist mechanisms of extraction - or whether capitalist mechanisms of organisation play a significant role not only in extracting value, but in moulding the very process of its production, which needs to be dialectically overcome, just as the factory-form of industrial capitalism was supposed to be. 


\section{Artistic circulation: between incorporation and autonomy}

This conundrum of co-optation and dissent is especially striking in global artistic circulation, which retains some of its specificity even in creative capitalism. Over the last three decades this sector has grown exponentially, both in terms of its geographic scope, its social volume and its density of relations. Currently, there are thousands of art institutions and art schools, hundreds of biennales, myriad foundations, associations, collectives, and galleries, and dozens of art fairs, art-dedicated banking branches, art consultancies, specialized agencies and council departments that absorb hundreds of thousands of people all around the globe. This is a large field, which has evolved out of the modern art institution, which itself was - as criticized by Peter Bürger - a contained exception of bourgeois society, the exceptionalism of which the aesthetic and political avant-gardes were supposed to overcome (Bürger 1984). The autonomous field of art emerged as a laboratory for the art of bohemian living, directed by the ideals of art, poetry, intensity, creativity and love, all of which undermined the dull routines of the bourgeoisie (Bourdieu 1996). This field had an at least partial autonomy, one driven by its own anti-economy, in which money was despised, art celebrated and artists revered. Obviously, it had its economic underpinnings and dependencies on the field of power, but this was a shameful secret that art discourse openly rejected.

With the recent expansion of artistic circulation, the autonomy of this field has weakened, while it has been partially incorporated into the markets, policies and mechanisms of social reproduction of global capitalist society (Stallabrass 2006; Graw 2009; Lind and Velthuis 2012; Malik 2013; Sholette 2017; Lind and Minichbauer 2005; Kozlowski et al. 2014). Yet, it is still relatively less incorporated in cycles of accumulation than other creative industries, to say nothing about traditional branches of industry. For example, global museums - which are large employers - are usually listed as non-profit enterprises, and this non-profitability remains an integral part of their corporate policies, business models and their expansion as globally recognized brands. Another example is bohemian ideology, which is cherished on the art market as a sales point, while motivating thousands of students to get indebted in order to study fine arts, supporting what Greg Sholette calls the "bare art world" (Sholette 2017, 54).

On the other hand, artistic circulation shares similar traits to other social fields in cognitive capitalism, fields on which capital does not directly accumulate [by the means of organizing production and the direct employment of labour power (Vercellone 2007)], but on which values are generated that are indirectly captured for accumulation, such as in higher education (Szadkowski 2015). The good and frequently discussed example of such capture is the process of gentrification, which David Harvey analyses in his essay on the "art of rent" (Harvey 2006), and Sharon Zukin labels an "artistic mode of production" (Zukin 1989, 176- 
192), in the framework of which artists contribute indirectly to the real estate value, which rentiers and capitalist then proceed to siphon off, leaving artists with naught.

Another example of the integration of financial capitalism in social systems is financial capital's function as a nexus of social reproduction of the rentier class on a global scale. As Fraser has pointed out, it is enough to look at the boards of leading art institutions in New York to spot many people who are also mentioned on the Forbes 500 list (Fraser 2011, 114-116). In the universe of contemporary art, a semblance of meritocracy is underpinned by class hierarchies, which enable the privileged to acquire and hold more prominent positions in this sector. From the throngs of young artists or independent curators roaming the network, those who really "make it" usually come from a more privileged background. The illusionary flatness of circulation is in fact a strict hierarchy, as in the chaos of circulation only a few win while many lose, and success depends on having access to various forms of capital.

In terms of organizing work, highly individualistic models of studio artists are mixed and matched with more recently introduced trajectories of freelancers and the self-employed (independent curators, project artists), the institutionalized employment of technicians, accountants or curators, academic positions in higher education, a plethora of temporary jobs in NGOs and projects, all underpinned by the free labour of assistants and volunteers. Despite this diversity, flexible and project-related systems of organization are dominant in this sector, where even larger institutions organize their content-related operations (educational programs, exhibitions, etc.) as projects, activating both their employers, freelancers and volunteers to maximize efficiency.

The systems of value adopted in artistic circulation reflect the fundamental paradox of this field, which is caught between nostalgia for artistic autonomy and its more recent incorporation into the social and economic systems of global capitalism. People in art refer to traditional bohemian beliefs in the value of art, but rearticulate them as demands for personal freedom, creativity and self-directedness that are specific to the new spirit of capitalism, as mapped by Free/Slow University of Warsaw in its research on the Polish field of visual art (Kozlowski, Sowa, and Szreder 2015b). The typical exceptionalism of art, namely its own belief in its having a special status, which legitimizes personal sacrifices, and which Hans Abbing criticizses as one of the reasons for artists' poverty (Abbing 2014), is reformulated as a more down-to-earth assessment of networked reality, wherein it is not only artistic talent that matters, but also the social skills of the networker. Also, people seldom subscribe to a romantic ethos, at least not in the Polish field of art; they are not willing to make sacrifices for art's sake, but are rather testing their chances of establishing a professional trajectory that would enable them to do both - to make art and make a living. In this way, the topsy-turvy economy of art, which is typical for the autonomous field of art, the developed form of 
which emerged in the 19th century European bourgeoisie societies (Bourdieu 1996), is recalibrated within strategies adopted by people working in this field, who consider their present sacrifices as investments - in prestige, connections, skills - the conscious aim of which is to generate the capitals utilized to stabilize their prospects. In sum, the field of art carries over some of the bohemian promises of art-centred life, but rearticulates them in response to the project-related system of production and a projective order of worth, which in itself has developed in response to the artistic critique of capitalism.

\section{Productive withdrawals}

The dialectic between incorporation and autonomy provokes diverse forms of resistance strikes, boycotts and occupations. They can all be categorized as productive withdrawals, which, by debunking exploitative institutional apparatuses of artistic circulation, forge new assemblages, ones that sustain art as a practice of freedom (Szreder 2017).

Productive withdrawals carry on the legacy of the art strikes dating back to the 1930s. These strikes challenged the art institution in the name of art as a practice of living, which artistic institutions were supposed to endorse but did not, as least according to the artists on strike. Artists like Gustav Metzger, Marcel Duchamp, Lee Lozano, Mladen Stillinović or Goran Dordjević withdrew or contested the field of art, because it did not stand up to the values of bohemian living, of imagination embodied in daily existence. Thus, they contested a system that contained art's autonomy within class society and the capitalist economy, thereby corrupting it. Classic art strikes addressed the dialectic of resistance and corruption, of promises given and failed. For this reason, many contemporary theoreticians of productive withdrawals refer to this legacy to deal with similar paradoxes around defining creative labour in contemporary capitalism (Kunst 2015; Lazzarato 2014; Raunig 2013a; Shukaitis 2014).

The recent wave of productive withdrawals - even though it riffs on the classic legacy of art strikes - differs because of its collective character, however. The strikes of Stillinović, Duchamp or Metzger had the status of artistic gestures, and as such they drifted institutionally and discursively to the status of being "just" art, even if it was not their initial impulse. Productive withdrawals refer to the collective actions of art workers who adopt bohemian demands but rearticulate them in the context of artist fronts, trade unions and associations, with reference to the legacies of strikes organized by Art Workers Coalition (1960s), Artists' Union (1930s) or neoists (1990s) (Bryan-Wilson 2010). The subjectivities of art workers themselves develop in response to the transforming systems of cultural 
production (Apostol 2015). They target artistic circulation as a site of work and extraction, not as a nostalgic recollection of artistic autonomy (and its exceptionalism), but as driven by a collective demand for better wages, social security, freedom. As I argue below, precisely such responses to networked modes of production institute the common, since, instead of cynicism, opportunism and fear, the striking multitude institutes solidarity and mutualizes social production.

Owing to productive withdrawals, the same networked modes of production, which otherwise facilitate the extraction of social labour, are progressively revamped. From this point of view, I am getting closer to Virno's aforementioned insights into the "neutral core" of post-Fordism. He states:

$[\ldots]$ it is necessary to rise up from these "bad sentiments" [i.e. opportunism and cynicism - KS] to the neutral core, namely to the fundamental mode of being, which, in principle, could give rise even to developments very different from those prevailing today. What is difficult to understand is that the antidote, so to speak, can be tracked down only in what for the moment appears to be poison (Virno 2004, 84).

Later Virno emphasizes that "we can hypothesize that every conflict or protest [in postFordism - KS] will take root in the [...] »neutral core" which, for the moment, manifests itself in these rather repugnant forms [i.e. of opportunism and cynicism - KS]" (Virno 2004, 88). When Virno discusses the "neutral core", he is speaking about forms of social organization specific to flexible capitalism. When these conditions are articulated in accord with capitalism, we see "bad sentiments" such as opportunism, cynicism and fear emerge. When targeted by progressive social formations, the same conditions of production can give rise to modes of collective autonomy, direct democracy and self-governance.

\section{From structural opportunism to entrepreneurs of the self}

Structural opportunism is not a moral stance, but a highly individualistic relation of production, arising because art workers - always moving between projects - need to chase interchangeable opportunities. My understanding of this situation is inspired by a nonmoralistic definition of opportunism, which Virno forges to discuss flexible labour markets in post-Fordism: 
The roots of opportunism lie in an outside-of-the-workplace socialization marked by unexpected turns, perceptible shocks, permanent innovation, chronic instability. Opportunists are those who confront a flow of ever-interchangeable possibilities, making themselves available to the greater number of these, yielding to the nearest one, and then quickly swerving from one to another. (Virno 2004, 86)

People chase the flow of interchangeable opportunities by turning their reputations, social contacts, skills and emotions, into capitals. This enables them to gain access to future opportunities and offers them the ability to stir networks in a direction considered as advantageous by their "owners", thus harnessing social and individual labour in the networkspecific value form. In this manner, structural opportunism moulds art workers into entrepreneurs of the self, one of the dominant modes of subjectivation in artistic circulation. Foucault dissects this figure in the context of neoliberal discourse, in which an "entrepreneur of one's self” is “one's being for oneself one's own capital, one's own producer, one's own source of earnings" (Foucault 2010, 226). In other words, a cultural producer is structurally enticed to consider his/her own knowledge, skills, emotional capacities, social networks as a form of capital to be invested in for future gains.

In this wicked manner, labour power is ideologically presented as if it was a capital, which is simultaneously true and not true. It is not true, because just like on a classical labour market, the labourers are in a drastically disadvantaged position, and enhancement of their labour power mainly serves people who purchase such luxury items - the capitalists themselves. On the other hand - and here artistic circulation proves an interesting case in point - in the situation of structural opportunism specific to flexible systems of production, people who capitalize on themselves (and others) are better able to find better opportunities and thus secure access to pools of accumulated social labour. Given an advantageous situation a micro-entrepreneur can outsmart the system and build his/her position to pick and choose jobs, opportunities and construct his/her professional portfolio, one not bound to a single employer nor subsumed by a given work discipline. This capacity of some to move freely is unequivocally praised by such sociologists such as Jean-Michel Menger, who generalizes from these exceptional situations by presenting them as entrepreneurial models for other precarious workers (Menger 1999). Clearly, however, such is not the case for majority of people operating on the artistic circuit, not to mention other precarious people. Freedom - as sociologists Andrew Ross and Guy Standing have proven becomes precarity when not coupled with other resources like education, social contacts and means of subsistence, the lack of which drives people into a state of unwanted dependency, forced to beg for any work whatsoever and chase opportunities without rest or remorse (Standing 2014; Ross 2009). 
But there is another important side effect to becoming entrepreneurial. The entrepreneur of the self is not only individually responsible for his/her own success when competing on an open market with other entrepreneurial individuals. Such an entrepreneur establishes an instrumental relation to his/her inner and social self, eradicates bonds of solidarity with other cultural producers, and tries to outcompete them in securing individual access to opportunities. And this access is mediated by the capitals at his/her disposal, as in the process of acquiring social and symbolic capitals he is not only capitalizing on his/her own labour, but also - or even especially - the labour of others.

\section{Social and symbolic capital}

As I already indicated in the introduction, to analyse the complexities of artistic circulation, I refer to a sociological notion of social and cultural capitals inspired by the theory of Pierre Bourdieu. Bourdieu adopts Marx's notion of value as objectified human labour. In capitalism, labour is harnessed in capitalist value form and ultimately transformed into capital, which enables its owner to claim a share of future social production. Bourdieu's sociological amendment to this notion sees him focus not on economic capital, but rather he uses it as a model to understand the social reproduction, class distinctions and hierarchies structuring such social fields as art or scholarship and the strategies of actors operating within them (Bourdieu 1996).

Both social and symbolic capitals are objectified human labour that determine the success of strategies aimed at the future acquisition of a position, a job, a reputation. Even though they are not directly expressed in money form, they are potentially convertible into financial gain. As Hans van Maanen suggests, social and symbolic capitals operate on three different layers: first, on that of embodied knowledge and social skills; second, on that of field-specific reputations and social contacts; and third, on that of the institutionalized knowledge and social density to be found within the structured fields themselves (Maanen 2009, 55-60). It is precisely this latter aspect of objectified social labour - of all the accumulated past and present efforts of people according to social field - that is akin to the general intellect.

On a structural level, artistic networks operate as generators of social and symbolic capital, expanding connections by means of projects, which can, but do not have to, be subsequently turned into a capitalist value form. They can be monetized when a market niche is found, for example by tourist industries or owners of real estate, who operate in cities such as Venice or Barcelona, and raise rents by enhancing the atmosphere forged by 
past and present generations. But these capitals can be harnessed - by corporations, capitalists, states or municipalities - in their raw form without being converted into monetary equivalents in order to acquire prestige or enhance soft power. Generally speaking, the collective and frequently underpaid or even unpaid labour of the multitude of artists, who still sacrifice themselves for the sake of art, maintains art's aura as something special and worthy of sacrifice. Abbing suggests that this aura serves as a resource for the elites of the sector, who cynically benefit from the sacrifices others make (Abbing 2014). Diedrich Diederichsen and Ratajczak propose to consider this generalized aura of art as anchoring the prices of particular artworks (Diederichsen 2008; Ratajczak 2014). This is still a matter of discussion though, as other theorists like Luc Boltanski rebuke the relationship between socially generated values and market prices, and instead focus on the arbitrary evaluations made by bigger market players, who operate as if they were totally independent in their judgements (Boltanski 2014). I think this latter argument holds, but only if one limits the analysis to the prices of individual artworks. If one considers the art market as a social universe, it is hardly conceivable - at least as it currently operates - that it could work as well as it does without the general aura of art as something precious and worthwhile. The usevalues produced and maintained by throngs of art producers and lovers, being mostly symbolic in nature (captured in the notion of symbolic capital), play their role as anchors of a general, positive evaluation of art, thus enabling speculations (just as general demand for wheat sustains the speculative behaviour of people who invest in financial instruments around fluctuating wheat prices).

The weakening of artistic autonomy does not mean that the fields in question are directly incorporated, but rather that they are formatted to enhance the generation of such forms of capitals, which can be more easily subdued in heteronomous pursuits. The good instance of this tendency is corporate sponsorship of art. For example, in a case disclosed by the activist group Liberate Tate, the Tate group in the UK has an established partnership with British Petroleum to art-wash its drilling operations (Evans 2015). When such deals are made, a general social labour, condensed in artistic circulation, is turned into capital controlled by more powerful players and directed for their own sake, thus enhancing brands, attracting visitors and legitimizing corporate agendas by granting art an aura. Another example here is the non-profit industrial sector - named as such by the activist group INCITE! from the USA (INCITE! Women of Color Against Violence 2009). Both non-governmental foundations and state agencies format circulation through their project-related modes of cultural funding, which stimulates the continuous flow of cultural projects, thus amplifying the over-production of artistic events with quantifiable outcomes. This means the social labour underpinning them is expressed in a networked value form that is easily capitalized by the funders themselves and other capitalist enterprises. 


\section{Capitalization of labour by entrepreneurs of the self}

What unfolds on a structural level is mirrored at the micro-scale of projects and personal trajectories. Apparatuses that regulate structural opportunism both facilitate and enforce the acquisition of capitals, i.e. objectified social labour, by individual cultural producers. In fact, the individual capacities of a successful networker are grossly enhanced as a result of such acquisitions. Artistic circulation is underpinned by pools of dormant knowledge and connections, which in themselves are results of past and present human labour, itself able to be temporarily amassed for any artistic project. For example, when a freelance curator organizes a large, prestigious exhibition, s/he might not own anything personally; however, because $\mathrm{s} /$ he is given temporary access to accumulated capitals, $\mathrm{s} /$ he is able to pull off very ambitious undertakings in a relatively short time. But artistic circulation is a winner-take-all economy, as Abbing shows with reference to the general artistic context (Abbing 2002). To understand this disparity Sholette devises the notion of artistic dark matter (Sholette 2011), a theoretical metaphor suggesting that people at top of the hierarchy - famous artists, curators, institutional functionaries, gallerists - accumulate capitals and resources at the expense of people who reproduce the circulation, but who are by themselves relatively deprived of visibility and connections. Sholette contends that the labouring multitude remains dark, not acknowledged in the universe, and is sustained by its continuing efforts. Yet again, similar to the case of prices of artworks, a more nuanced approach is required. The trajectories of successful entrepreneurs of the self are very rarely directly related to the abuse of any individual labourer. They are underpinned by the general social labour of artistic dark matter, which is a dynamic category made up of people who are not recognized for their efforts at a given moment (due to the winner-takes-all logic, this means the vast majority of the artistic universe). Moreover, and this is a fundamental difference between "regular" capitalists, as Marx described them, and the entrepreneurs of the self who compete for social and symbolic capitals, expropriation is here not mediated by contractual employment. On the contrary, the capitals in question are of a contextual nature; they cannot be quantified or monetized directly (though they can be moulded into forms that are prone to capture), and not extracted by employing anyone. When I say that such capitals are invested, I do not mean it in the literal sense of investing money as capital in the pursuit of surplus value. Rather, I have in mind people who invest - their reputations, knowledge, social contacts - in their undertakings, and a few of whom are far more successful than others, not only in terms of recuperating their own investments but also a disproportionate portion of the accumulated social labour. In such situations, the distinction between labour and capital is not predefined, as it is in regular employment wheres capitalists purchase labour to extract surplus value. Instead, it is processual and defined only retrospectively. For example, people may engage 
in a project as freelancers, such that nobody actually employs anyone. Each person invests him- or herself in it, but only a few persons will thrive by accumulating enough kudos to secure access to future opportunities. The remainder end up with naught. Only in retrospect can they be identified as labour-givers and not as accumulators of capitals. Another complication is that this accumulation happens not only (and not even predominantly) around projects, but within the vast, chaotic nexus of networks and transient relations. For entrepreneurs of the self thrive on the general social labour accumulated in circulation and not on the small bits acquired as a result of individual projects. It is important here, I think, to underline this systemic perspective. Otherwise, instead of developing a sharp dialectical analysis of circulation, we end up describing a typical tit-for-tat wherein networkers squabble with each other for bits and pieces of prestige or connections. I would consider such conflicts properly as squabbles rather than as struggles, as they usually derive as symptoms - from a systemic arrangement that turns people into entrepreneurs of the self, obsessed with their own precious investments.

People who manage to maintain a position in circulation are totally deprived of access to capitals only very seldom. When, together with the team of Free/Slow University, we conducted the aforementioned research into the division of labour and distribution of capitals in the Polish field of visual art, we were surprised by the general complicity of our respondents with the structures of the field. Even if people voiced more detailed concerns about their economic conditions, or the precarity or burdens of networking, they generally tended to agree with how the field is organized. When we assessed these outcomes, we concluded that the results were possibly skewed by the fact that we researched people who are still active in circulation, i.e. present and visible, and managing to acquire enough capitals to keep circulating by accessing new projects, frequently at the cost of their own unpaid labour or other sacrifices. The ones who are really deprived are the ones who have withdrawn from circulation or were excluded from it. Such exclusion, as Boltanski an Chiapello argue, is a double deprivation and a form of exploitation embedded within a connectionist society (Boltanski and Chiapello 2005, 346-355). On the one hand, the excluded do not have access to circulation and are downgraded to the status of an anonymous resource; they are mobilized only for projects initiated by others and from which others benefit the most. Adding insult to this injury, the excluded are deprived of access to the only platforms that would enable them to voice their concerns publicly, to denounce the experience of injustice. This is because, in circulation the only platforms of public visibility are those accessed via circulation. As a result, the excluded disappear, their presence is eradicated, they become a real dark matter and a potential hotbed for resentment or action. 
In the cruel economy of artistic circulation, capitals are not equally distributed. Their acquisition depends on a general standing in hierarchy and is contextualized by a portfolio of capitals at the disposal of a networker. Basically, the rule is that the person with the largest amount of capitals will benefit the most from any given project. On the other hand, others may also benefit from taking part in a project enhanced by the capitals of somebody more famous than themselves, someone able to count on the connections, visibility or knowledge that $\mathrm{s} /$ he brings. But in a larger picture, even small differentials accumulate over time and constitute skewed hierarchies between celebrities and dark matter, i.e. people who manage to get access to better opportunities tend to secure even better access in the future, entering more prestigious projects at higher positions, thus making it possible to get a larger share in the future results of collective undertakings.

This law of social accumulation, which enables people who have more capitals to acquire even larger shares of social labour, is particularly important for maintaining class hierarchies on a global scale in a seemingly horizontal or flattened world of networks and flows. When Gielen criticizes freelance curators as "joy riders" - opportunistic and cynical who freely roam the globe in search of more interesting and beneficial undertakings (Gielen 2009, 36-37), he is actually describing people who already enjoy better positions in the network, while others are struggling to deal with the reality of precarity. But, more importantly still, the meritocracy supposedly underpinning their exploits is a convivial myth. Artistic circulation distributes its benefits mostly to people who have inherited an initial portfolio of capitals, either because of their class or because of the citizenship rent distributed in the form of free education, stipends, access to more beneficial labour markets in the countries of global North.

In my analysis of the cruel economy of authorship, I have identified two types of labour - love and pollination - that seem to be most often exploited in cultural projects (Szreder 2013). I refer to the labour of pollination as the general social labour involved in generating the human knowledge and social connections condensed in artistic circulation. The labour of love, which George Yúdice has analysed with the example of a large art event at the US/Mexican border, is a socially necessary labour contributed by curators, assistants, volunteers, who commit themselves to a given project by facilitating the contextual work of social reproduction, which often goes unnoticed but is crucial for the success of any more ambitious artistic undertaking (Yúdice 2003, 287-337). This labour of social reproduction is structurally equivalent to the invisible labour of women, who maintain capitalist systems of production, even while not being formally employed. A general critique of authorial capture was formulated by Jan Sowa in his depiction of contemporary art, in which he points to the exploitative relation between authors and the common (Sowa 2014). 
The depreciation of support labour harks back to the art field-specific system of beliefs, which sanctifies authorial positions as carriers of social value (Bourdieu 1996, 166173). The F/SUW research clearly confirms it. When our respondents were asked to indicate who contributed most of their time to a given project, all professional groups equally named artists and support personnel. However, when respondents were asked who contributed most to the success of an exhibition or festival and should be honoured as such, only artists and curators were named (Kozlowski, Sowa, and Szreder 2015a, 208-234). This ideologically skewed assessment was voiced by everyone, without any significant difference between artists, curators or assistants. But this symbolic depreciation is a very ambivalent mechanism looked at from the position of an individual artist who is often "paid" only in a symbolic recognition. Consequently, artists are expected to work for free, only for the promise of a future accumulation of symbolic capital. However, they often end up working for nothing, because only very few mechanisms exist for converting their reputations into "real" money; the majority of projects are unpaid, jobs are scarce and the art market serves the ideological function of arousing aspirations rather than of providing a real means of subsistence. In this sense people who work as technicians (some of them trained artists who have parallel art careers) and have stable sources of income are in a better position than artists who sacrifice their own free time for merely symbolic recognition (in this situation we could read a symbolic capital, with Abbing, as an illusionary construct).

The entrepreneurial mode of subjectivity proves to be detrimental or even directly harmful to most people, forced as they are to compete and self-capitalize without having any means to win the competitive games of structural opportunism. But by taking part in circulation, they do generate capitals, which are siphoned off by those who can afford strategic investments, and thereby secure their privileged access to the fruits of social labour. The subjectivity of art workers, though also forged in the process of expropriation, considers this relation in accordance with its social truth, i.e. as exploitation. This progressive subjectivity tears through the ideological aspirations of entrepreneurialism of the self, supporting self-organization and motivating struggles, as a result of which both means and gains of social production can be socialized and the common instituted. 


\section{Better social time machines ${ }^{1}$}

In the following sections, I look for varied instances of instituting the common in artistic circulation. Here, I turn more directly to empirical instances of such instituting, that is, the productive withdrawals due to which people collectively reclaim the temporal arrangements, means and results of networked production. Consequently, employing my methodological premise of following the conflicts, I do not provide an overarching definition of what the commons is, but rather look at how it is instigated by the dissenting multitudes. Instituting is understood here not only in the narrow sense of making new institutions (though I discuss a plethora of collectives, clusters and the like), but also as instituting new social norms, such as paying wages for artworks, or even instituting new, better social time machines. Following on from this premise, perhaps somewhat counterintuitively, I start by discussing the commons not as a (material or immaterial) resource but as a different approach to the apparatuses that regulate the flow of social time.

Apparatuses that form artistic circulation organize social energies by regulating the time patterns, in which they unfold. The time of global art circulation is comparable to the time of stock exchanges, where values and stocks are flipped in nanoseconds. Framed by such temporal patterns, people speculate about the future values of artistic trajectories and art objects - commodifying them both. Such circulation is organised by the patterns of speculative time complex, as analysed by Suhail Malik and Armen Avenessian, which remixes future, present and past, eradicating spaces in which human reflectivity and agency could potentially unfold (Avanessian and Malik 2016).

For precarious art workers, every passage from one project to another, every passing opportunity, every deadline and every application is a time machine through which the future enters into the present, only to eradicate the real possibility of changing anything, as every project, deadline and application results in yet another project, deadline and application. Having a successful career mainly means that one gets more of the same, i.e. a celebrated networker needs to circulate even more, make more projects, answer more emails and attend more events, as Hito Steyrl sensibly points out (Steyerl 2016). It sounds like an awful lot, unless one can afford to hire studio assistants. But even this might not help mitigate feelings of being spread too thin.

Art workers, when integrated into the art market, expect returns on their current precarity. But in the cruel economy of art, many artists will never get anything except what they already know - precarity and debt. This nexus forges an iron link between debt and

\footnotetext{
${ }^{1}$ The concept is gleaned from Suhail Malik's lecture held at the Bartlett School of Architecture, London, March 2017.
} 
the art market, which is mediated, at least in the USA, by student loans, as is succinctly analysed by Sholette, who takes up the collective research done by such groups as Occupy Museums (and their project Debt Fair), Strike Debt or bfamfaphd (Sholette 2017, 53-77). Caught in the capitalist debt loop, which Lazzarato and David Graeber analyse (Graeber 2012; Lazzarato 2012), artists are forced to compete in the art market, from which they are not able to escape, but in which they are not able to succeed. It is indeed a bare art world, in which the economic underpinnings of artistic circulation overshadow its own claims for autonomy.

Productive withdrawals, as modes of instituting the common, are also, or especially, important because they interrupt these routines, building new, better social time machines. The multitudes on strike try to establish different relationships between present and future, as they struggle to come up with alternatives to the deadened productivity of artistic circulation, in which everything moves so that nothing can change. When Liberate Tate unmakes the partnership between the Tate and British Petroleum, they operate within a clearly strategic horizon. They reinvent the Tate as an institution of the common, the aim of which should be to project a vision of the future, one that can be democratically deliberated to protect the multitude from climate mayhem. Instead of expecting individual returns on their precarity, members of this collective invest themselves in collective futures. In this sense, Liberate Tate is both a prefiguration of an institution of the common and an alliance advocating enactment of such a model in general social praxis, which is constituted in the process of dismantling neoliberal time machines.

These better social time machines are put in motion to gain collective access to the means of subsistence. The main demand of the organizers of Art Strike in Poland in 2012 was to introduce retirement programs for artists, who are currently excluded from participating in the public pension and health systems due to their intermittent working patterns (Figiel 2014). Art Strike disrupted social illusions that such a miserable condition is the individual responsibility of entrepreneurial artists. In this way, Polish art workers resonated with other advocacy groups, like the American W.A.G.E. (Working Artists and the Greater Economy), or the Precarious Workers Brigade and Artist Union in the UK. Members of these collectives debunk the ideology of return-on-precarity, debunk the mythology inherent to most artistic circulation and unmake the concept of artists as entrepreneurs of the self. To advocate for more reasonable policies, politicized art workers underscore the strategic and general character of artistic contributions to the cultural commons, thus struggling for a collective right to the future (spelled out in the basic terms of pension, healthcare, social welfare). They do this not only for themselves, but for other precarious people as well. 


\section{Entrepreneurship of the multitude}

Structural opportunism is both a mode of production and a site of struggle. On the one hand, it is the self-centred struggle of networkers, of entrepreneurs of the self, who compete, one versus the many, for access to opportunities. But this negative sentiment - of cynical, opportunistic entrepreneurship, the underside of which is anxiety for individual survival can be rearticulated differently. Characterizing art strikes, Raunig has drawn a paradoxical figure of industriousness, orgiastic, self-directed and self-governed productivity of the multitude on strike (Raunig 2013a, 121-122), which I have picked up on with the notion of productive withdrawals. When art workers strike, the argument goes, they do not rest idle; on the contrary, they generate politically charged contents, affects, situations, values and resources. These values are of a different ilk to those prioritized in artistic circulation, the organizational grammar of which aims at continuous expansion, prompting the overproduction of interchangeable projects, the content of which matters insofar as it enables the generation and privatization of capitals that express the values produced in a networked form. This is the credo of structural opportunism. When the striking multitude interrupts interruptions, which are imposed by the networked form of value to expand the circulation and speed up social production, it fills those spaces with collective activity, selfvalorised as politics, joy, or both. For example, when art workers in Milan squatted Galfa Tower, a corporate high-rise in city centre, it was both an anti-capitalist statement and an art workers' festivity, in that they refused simply to engage in making yet another project, and instead indulged in production of the sort that did not need to be expressed through individualized portfolios of social, symbolic or economic capital in order to be valorized (Spinelli 2018).

Negri and Hardt evoke entrepreneurship of the common to talk about the selfdirected labour of the multitude (Hardt and Negri 2017, 139-153). What interests me here, though, is the progressive moulding of networked production, which undoes structural opportunism. The entrepreneurship embedded in productive withdrawals challenges what happens between the individualized producer and the tenuous flow of interchangeable opportunities. Usually, this in-betweenness is traversed by individuals competing for interchangeable opportunities. But when art workers strike, they enact opportunism of a different sort, that is, the tactical seizing of opportunities for the sake of collective actions, something that Michel de Certeau discusses in the context of social movements and urban guerrilla in his Practice of Everyday Life (Certeau 1984). Such opportunists not only seize opportunities for themselves, but also create them for others. In this sense, opportunities become socialized and various semi-open structures evolve, securing access on a cooperative and not competitive basis. This notion applies to countless occupied art centres, like Isola Art 
Centre in Milan, S.a.L.E. Docs in Venice, or Green Park in Athens, as well as to artists-run spaces and cooperatives, like GoldexPoldex in Kraków, the Free/Slow University of Warsaw or Critical Practice in London (Baravalle 2018; Isola Art Center 2013; Critical Practice 2011; Sowa 2009; Szreder 2015b). These collectives entrepreneurially collate resources, secure access to a space, generate the willingness and enthusiasm of people, and then share them among their friends, comrades and associates, thus socializing access to opportunities.

What is the qualitative difference between this mode of access and the one of structural opportunism? Socializing opportunities means that access is not mediated by privatized capitals but rather granted due to a shared engagement in the necessary social labour, which is an open arrangement per definition, one in which every art worker is invited to take part, and wherein only his/her willingness to engage in a process of commoning is a factor determining his/her access to the common. This engagement can take various forms. Sometimes it is about occupying, building and maintaining the space, as evidenced by the study of a group process conducted by the Macao people in Milan - 69,300 hours were collectively spent refurbishing the Macao building to turn it into a cultural centre (Spinelli 2018). In other cases, like in Critical Practice, an open research cluster associated with Chelsea College in London, group members organized collective processes based on shared enthusiasm, collating their scarce resources to facilitate carrying out a shared idea.

Productive withdrawals are open, because the more art workers engage, the more efficient these struggles are. And the access thus generated is distributed not only among the comrades on strike, a core group of initiators, but also among newcomers, who sustain the (social) space thus emerged when the initial impulse is gone, which gets us closer to an idea of instituting. This suggests persistence in time, as well as a strategic and not merely tactical perspective. The perpetual rhythm of securing, creating and sharing opportunities is crucial for sustaining any nascent institution of the common. For example, the longevity of the Isola Art Centre, as described by Spinelli, was due precisely to the persistent openness of its organizational form. It welcomed new waves of artists-activists, who engaged in the institutional process by utilizing opportunities and generating new ones that their successors then took over and continue to develop (Spinelli 2018).

Importantly, such entrepreneurship of the common can devolve into a core activist clique, a form of clumsy directness that distributes opportunities among closed networks of camaraderie based on personal connections. This leads only to degeneration, stalls networks and diminishes their potentials. I advocate here that the circulation should be approached dialectically, not rebuked entirely, and devolved into cloisters of localized echo chambers of like-minded individuals. It is about revamping circulation on a global scale as the entrepreneurship of the multitude moves about in the open spaces of an international network, rearticulating symbolic and social capitals as reputations embedded in struggles and 
movements based on distributed trust. For example, when, together with Greg Sholette and Marco Baravalle from S.a.L.E. Docs, we curated Dark Matter Super Collider, an open exhibition structure, organized in parallel to the opening of Venice Biennale in 2017, which featured dozens of examples of political art from the entire world, the process of soliciting materials activated networks of mutual trust between artists and activists on a global scale. Thanks to the open call made, dozens of examples of political art were donated to S.a.L.E., brought in suitcases by people attending the opening. As Super-Collider accelerated social energies accumulated previously in art-activist networks, it was possible to put up the exhibition with the help of the tiny financial investment of a couple of hundred euros. The social and symbolic capitals involved were socialized and distributed, fed back into the networks in which they originated, because of the programmatic inclusivity of this structure, which redistributed opportunities and visibility to people engaged in social struggles all around the world. On this occasion, S.a.L.E. operated in contrast to the typical biennale pavilion, which offers chosen individuals exclusive access. This formula is also repeated by progressive public institutions, as for example when they engage in organizing networks for the public's benefit, as we saw with the Association and Museum of Arte Util, an international coalition of museums, artists and activists who aim to mobilize art for social utility, to harness and share opportunities - like new commissions or exhibitions - for the benefit of collective endeavour (Byrne, Medina and Saviotti 2018). In other cases, the socialization of opportunities does not have to be based on conviviality but rather feeds on tension. When the aforementioned Liberate Tate organized their actions in the Turbine Hall of Tate Modern, they seized on an opportunity for collective action, wresting the visibility granted by the institution for the sake of its progressive revamping. The value thereby generated should not be counted as a sum of capitals generated individually, but rather as an accumulation of social energy and public attention, which here eventually disrupted ties between the public art institution and extractive corporation.

\section{Socializing the results of social creativity}

Super-Collider, however, was "just" a project, one made possible because S.a.L.E. managed to secure long-term access to resources and social labour, which were not privatized as individual capital to be used to extract rent or secure individual opportunities, but rather for the sake of a collective. The typical mode of capitals acquisition through capturing social labour (either of love or of pollination) is reversed in such instances. Very often instituting the common is based on mechanisms that redistribute the effects of social cooperation for 
the sake of the collectives involved. My discussions of capitals distribution in previous projects have suggested that involving a person with higher amount of capitals - i.e. one who is better connected, more recognized, etc. - might prove beneficial for everyone involved, as these intangible forms of capital tend to get distributed to the teams of co-operators as well, precisely because their individual success depends on the success of the collective undertaking, the chances of which are enhanced by the capitals of those involved. However, in the context of a competitive network, this tendency is overwritten by another law, according to which a person with a higher amount of capitals secures a larger share of the social product. But the entrepreneurial multitude challenges this second law of networked dynamics by redirecting reputations, visibility and connections for the benefit of the collective. This happens when a respected philosopher, like Negri, Sholette or Raunig, responds to an invite by an art-activist platform like S.a.L.E., which makes sure that the exchange is mutual and collectively enjoyed in a non-hierarchical environment. Sometimes simple gestures work best - food is shared, work is done together and credits are spread equally to everyone involved, and hospitality is mutualized by exchanging invitations. At other times, it can be more complicated. When the Isola Art Center fought against the gentrification of its home district in Milan, they deliberately utilized their social connections and international networks, calling prominent artists and intellectuals to help with their cause, and with getting things done by drawing on their participation, art, reputations (Isola Art Center 2013). Another example: when Polish art workers went on art strike, more established artists promptly voiced their support, committing their reputations to the struggle. This translated into real collective gains, such as securing exhibition fees for everyone and not just a select few. We can describe this as a mechanism of capture embedded in the entrepreneurship of the common, a radically pragmatic mode of reversing the expropriations of social labour for the benefit of the multitude.

Another reversal of expropriation challenges the division between recognized (attributable) and unrecognized (anonymous) labour - between authorial pursuits and a labour of love or labour of pollination. As indicated above, this division of labour only seemingly works in favour of artists or people who struggle to build their individual symbolic capital, as they often end up with neither money nor opportunities, and are instead paid only in empty promises of future gains (embedded structurally in the economic architecture of symbolic capital). Instituting the common cuts through this Gordian knot by equalizing access, which is not dependant on capitals but rather defined through shared engagement. The most entrepreneurial multitudes - like the activists occupying Macao in Milan - manage even to generate financial gains, which are shared between all involved as a kind of basic income. One only needs to spend enough hours monthly on collective undertakings (regardless of whether it is more intellectual or physical) to receive a share in revenues, 
which are equally distributed among everyone involved, incentivizing the sharing of workloads and urging solidarity.

Another mechanism of breaking down divisions between different professional groups involves mutualizing the benefits of projects conducted in the spirit of the common, accounting for all types of labour and forms of capitals. Simply speaking, paying wages to all, crediting everyone, multi-authoring results, creating non-hierarchical spaces where everybody can mingle together and enact inclusive forms of governance. Even the introducing of such simple measures is no small feat, and is continues to be rare in artistic circulation, which offers a semblance of flatness, while cultivating distinctions. Equalizing the wages, credits, and social contacts generated in projects, contributes to instituting the common. This is why most spaces or projects with more progressive agendas pay utmost respect to simple courtesies, financial matters, mentions and credits - rewiring the loopholes that otherwise facilitate a capitalization on the labour of others. At a more general level, equalized distribution is secured by experiments with open licencing, the creative commons, the art commons and other radical licences like copy far left, all well recognized and widely discussed as a partial measure against expropriation of social labour.

On a political level, this kind of equalization is expressed in the political identification of art workers or cultural/creative producers, which aims at creating solidarity between professional groups that are otherwise easily exploited for the sake of networked governance, a governance that thrives on atomization, cynical opportunism and selfentrepreneurialism. Wages for art work is such an important postulate, because it disincentivizes freelancers from succumbing to competitive entrepreneurialism, while incentivizing all to struggle for a shared benefit and instituting laws of equivalence, the important side effect of which is preventing exclusions.

As aforementioned, exclusion is the ultimate form of exploitation in our networked society. The excluded - the dark matter of the artistic universe - are utilized as a resource for the careers of those who keep circulating. On the other hand, those who circulate sacrifice a lot just to maintain themselves in circulation, they capitalise on whatever they have, in turn sustaining the sparkling careers of the few. Not only that, as Bifo Berardi and Angela McRobbie have suggested, in a system that individualizes success, failure must also be suffered in solitude, causing depression to become the professional illness of freelancers, who take individual responsibility for structurally induced risks (Berardi 2009; McRobbie 2011). In this context, instituting the common means mutualizing risks, or de-individualizing desire in order to maintain shared support structures and creating bulwarks against exclusion. All collective initiatives not mediated by the flow of interchangeable opportunities might serve as such bulwarks, because they sustain the social trust generated in cooperation and struggles. When art workers partake in becoming common, they are not alone. And this 
sociality has political potential, because support structures serve as spaces of mutual recognition, where people can act in front of their equals, discuss issues of importance, formulate and execute agendas. Otherwise, the excluded, those who suffer the most, remain unrecognized not only in artistic circulation but also to each other. In this way instituting the common is a condition of public action in a circulation where all that is solid melts into flows.

\section{Wasps, orchids and extra-institutional assemblages}

I have purposefully avoided discussion about the institutional forms that can potentially emerge in the process of constituting the common. Instead, I have focused on tracing actually existing, progressive responses to the tensions embedded in artistic circulation, tensions that revolve around the fundamental conflict between socialized labour and privatized capitals, and that address the dialectics of artistic networks, which can both condense into the poison of opportunism, cynicism and fear, or be constructed as mutualized structures of cooperation, redistribution and political action. Instituting the common, in other words, is distinguished by what it does and not by what it is. I do not for even a second presume that a university-affiliated group of researchers is exactly the same as an activist-run and occupied space. But even if they are not identical, they often share affinities, processes and struggles, insofar as they find themselves challenged by similar systemic pressures. This is another important advantage of dialectical analysis, which supports an in-depth understanding of systemic pressures as political opportunities due to their synthetizing function, whereby they form otherwise unlikely alliances. A progressive university cluster is no less exposed to neoliberal assaults on social welfare than a collective located in the midst of the most gentrified city in Europe. For this reason, more often than not such clusters transversally align themselves in progressive constellations, emerging for the sake of socializing the means and results of social labour. I think that this process would not have happened were it not for an unprecedented level of systemic integration, introduced by the ever-expanding networks (and nexuses of expropriation) constitutive of artistic circulation.

The institutional forms of the common provoked by this tension are as diverse as the forms of life of the multitude. This diversity is mirrored by the multiplicity of terms used to denote these initiatives, as people talk about monster-, mock-, pata-, conspirational-, exodus- and alter-institutions. It is possible, though, that the institutions in question will not be single institutions at all. Just as wasps and orchids - in the account of Gilles Deleuze and 
Felix Guattari - form new assemblages, mutualizing not only their habits, but also their beings, so, too, can the common be instituted as assemblages of collectives, initiatives, public institutions, individuals and affinity groups that sustain the common by reversing the expropriations of artistic circulation, mutualizing gains and seizing opportunities.

The commons - as I have argued - is not only instituted at the micro-scale of a small collective, a cosy activist group, a passing occupation. The commons does not have to be based on principles of immediacy and direct contact; but sometimes operates on the scale of an entire country, like Polish art workers or W.A.G.E. have done in their struggles for wages and social security, or of the planet, such as when a boycott in Sydney reverberated globally, inspiring action in Saint Petersburg. The commons can constitute and revamp scenes, networks, coalitions and swarms of glocalized dimensions. Information is shared, inspiration flows, connections are made and the general intellect is activated. These are not small feats and are achieved by using a variety of means, in some cases a radically democratic form of assembly, but in other radically pragmatic entrepreneurship of the multitude, getting things done in a networked coordination. These assemblages become cradles of an entrepreneurial multitude and of industrious art workers, who collectively seize opportunities to mutualize the benefits of social cooperation, recapturing capitals and dissolving them into the common. 


\section{References}

Abbing, Hans. 2002. Why Are Artists Poor?: The Exceptional Economy of the Arts. Amsterdam: Amsterdam University Press.

Abbing, Hans. 2014. "Notes on the Exploitation of Poor Artists." In Joy Forever. Political Economy of Social Creativity. Eds. M. Kozlowski, A. Kurant, J. Sowa, K. Szadkowski, and J. Szreder. London: MayFly Books.

Apostol, Corina. 2015. "Art Workers Between Precarity and Resistance: A Genealogy." Artleaks Gazette August.

Avanessian, Armen, and Suhail Malik (eds.). 2016. The Time Complex: Post-Contemporary. Miami.

Baravalle, Marco. 2018. "Capture, Subjectivity, Governance, Geography, Acceleration, Queering. On Cultural Alter-Institutions and the Case of S.a.L.E. Docks." Journal for Research Cultures: [unpublished manuscript].

Berardi, Franco. 2009. The Soul at Work: From Alienation to Autonomy. Los Angeles: Semiotext(e).

Boltanski, Luc. 2014. "From Object to CEuvre. The Process of Attribution and Valorization of Objects." In Joy Forver. Political Economy of Social Creativity. Eds. M. Kozlowski, K. Szadkowski, A. Kurant, J. Sowa, and J. Szreder. London: MayFly Books.

Boltanski, Luc, and Eve Chiapello. 2005. The New Spirit of Capitalism. London: Verso.

Bourdieu, Pierre. 1996. The Rules of Art: Genesis and Structure of the Literary Field. Cambridge: Polity Press.

Bryan-Wilson, Julia. 2010. “Art versus Work.” In ART WORK A National Conversation About Art, Labor, and Economics. Eds. Temporary Services. Chicago: Temporary Services.

Bürger, Peter. 1984. Theory of the avant-garde. Manchester: Manchester University Press.

Byrne, John, Gemma Medina, and Alessandra Saviotti. 2018. "Asociación de Arte Útil: A Nomadic and Multiform Platform for Usership." Journal for Research Cultures: [unpublished manuscript].

Carrillo, Jesús. 2017. "Conspiratorial Institutions? Museums and Social Transformation in the Post-Crisis Period.” Wrong Wrong Magazine June 26.

http://wrongwrong.net/article/conspiratorial-institutions-museums-and-socialtransformation-in-the-post-crisis-period.

Certeau, Michel de. 1984. The Practice of Everyday Life. Berkeley: University of California Press.

Critical Practice (ed.). 2011. Parade: Modes of Assembly and Forms of Address. London: CWC.

Diederichsen, Diedrich. 2008. On (Surplus) V alue in Art. Berlin, New York: Sternberg Press. Evans, Mel. 2015. Artwash: Big Oil and the Arts. London: Pluto Press.

Figiel, Joanna. 2014. "On the Citizen Forum for Contemporary Arts." Artleaks Gazette September 2014.

Foucault, Michel. 2010. The birth of biopolitics: lectures at the Collège de France, 1978-1979. Eds. F. Ewald, and A. Fontana. Basingstoke: Palgrave Macmillan.

Fraser, Andrea. 2006. "From the Critique of Institutions to an Institution of Critique." In Institutional Critique and After. Ed. J.C. Welchman. Zurich: JRP|Ringier.

Fraser, Andrea. 2011. “L'1\%, C’EST MOI.” Texte Zur Kunst September 2011.

Gielen, Pascal. 2009. Pascal Gielen: The Murmuring of the Artistic Multitude. Global Art, Memory and Post-Fordism. Amsterdam: Valiz.

Gielen, Pascal. 2013. Creativity and Other Fundamentalisms. Heyningen: JAP SAM Books.

Graeber, David. 2012. Debt: The First 5000 Years. New York: Melville House. 
Graw, Isabelle. 2006. "Beyond Institutional Critique." In Institutional Critique and After. Ed. J.C. Welchman. Zurich: JRP|Ringier.

Graw, Isabelle. 2009. High Price: Art between the Market and Celebrity Culture. Berlin, New York: Sternberg Press.

Hardt, Michael, and Antonio Negri. 2009. Commonwealth. Cambridge: Harvard University Press.

Hardt, Michael, and Antonio Negri. 2017. Assembly. New York: Oxford University Press.

Harvey, David. 2006. "The Art of Rent: Globalization, Monopoly and the Commodification of Culture." http:/ /www.16beavergroup.org/mtarchive/archives/001966.php.

INCITE! Women of Color Against Violence. 2009. The Revolution Will Not Be Funded: Beyond the Non-Profit Industrial Complex. Boston: South End Press.

Isola Art Center. 2013. Fight-specific Isola: art, architecture, activism and the future of the city. Berlin: Archive Books.

Kozlowski, Michal, Agnieszka Kurant, Jan Sowa, Krystian Szadkowski, and Jakub Szreder (eds.). 2014. Joy Forever. Political Economy of Social Creativity. London: MayFly Books.

Kozlowski, Michal, Jan Sowa, and Kuba Szreder (eds.). 2015a. Fabryka Sztuki. Warszawa: Bęc Zmiana.

Kozlowski, Michal, Jan Sowa, and Kuba Szreder (eds.). 2015b. The Art Factory. Warszawa: Bęc Zmiana.

Kunst, Bojana. 2015. Artist at Work, Proximity of Art and Capitalism. Winchester, UKWashington, D.C: Zero Books.

Lazzarato, Maurizio. 2009. "The Political Form of Coordination." In Art and Contemporary Critical Practice: Reinventing Institutional Critique. Eds. G. Raunig, and G. Ray. London: MayFly Books.

Lazzarato, Maurizio. 2011. “The Misfortunes of the »Artistic Critique« and of Cultural Employment." In Critique of Creativity: Precarity, Subjectivity and Resistance in the "Creative Industries.” Eds. U. Wuggenig, G. Raunig, and G. Ray. London: MayFly Books.

Lazzarato, Maurizio. 2012. The Making of the Indebted Man: An Essay on the Neoliberal Condition. Los Angeles: Semiotext(e).

Lazzarato, Maurizio. 2014. Marcel Duchamp and the Refusal of Work. Los Angeles: Semiotext(e). Lind, Maria, and Raimund Minichbauer (eds.). 2005. European Cultural Policies 2015: A Report with Scenarios on the Future of Public Funding for Contemporary Art in Europe. StockholmVienna: Iaspis-eipcp.

Lind, Maria, and Olav Velthuis (eds.). 2012. Contemporary Art and Its Commercial Markets: A Report on Current Conditions and Future Scenarios. Berlin, New York: Sternberg Press.

Lorey, Isabell. 2013. "On Democracy and Occupation. Horizontality and the Need for New Forms of Verticality." In Institutional Attitudes: Instituting Art in a Flat World.

Ed. P. Gielen. Amsterdam: Valiz.

Maanen, Hans van. 2009. How to Study Art Worlds: On the Societal Functioning of Aesthetic V alues. Amsterdam: Amsterdam University Press.

Malik, Suhail. 2013. "Civic Virtue in Neoliberalism and Contemporary Art's Cartelisation." New York: [unpublished manuscript].

McRobbie, Angela. 2011. "Re-Thinking Creative Economy as Radical Social Enterprise." $V$ ariant Spring.

Menger, Pierre-Michel. 1999. "Artistic Labour Markets and Careers." Annual Review of Sociology 25: 541-574. 
Ratajczak, Mikołaj. 2014. "Sztuka i praca. Od ekonomii politycznej produkcji artystycznej do krytycznej filozofii współczesnych form pracy.” In Skuteczność sætuki. Ed. T. Załuski. Łódź: Muzeum Sztuki.

Ratajczak, Mikołaj. 2015. "Wprowadzenie do teorii kapitalizmu kognitywnego: Kapitalizm kognitywny jako reżim akumulacji." Praktyka Teoretyczna 15: 57-95.

Raunig, Gerald. 2009. "Instituent Practices: Fleeing, Instituting, Transforming." In Art and Contemporary Critical Practice: Reinventing Institutional Critique. Eds. G. Raunig, and G. Ray. London: MayFly Books.

Raunig, Gerald. 2013a. Factories of Knowledge, Industries of Creativity. Los Angeles: Semiotext(e).

Raunig, Gerald. 2013b. "Flatness Rules. Instituent Practicesand Institutions of the Common in a Flat World." In Institutional Attitudes: Instituting Art in a Flat World. Ed. P. Gielen. Amsterdam: Valiz.

Ross, Andrew. 2009. Nice Work If You Can Get It: Life and Labor in Precarious Times. New York: New York University Press.

Sholette, Gregory. 2011. Dark Matter: Art and Politics in the Age of Enterprise Culture. London, New York: Pluto Press.

Sholette, Gregory. 2017. Delirium and Resistance: Activist Art and the Crisis of Capitalism. London: Pluto Press.

Shukaitis, Stevphen. 2014. "Artstrike and Metropolitan Factory.” In Joy Forever. The Political Economy of Social Creativity. Eds. M. Kozlowski, A. Kurant, J. Sowa, K. Szadkowski, and J. Szreder. London, Warsaw: MayFly Books.

Sowa, Jan. 2009. “Goldex Poldex Madafaka, or a Report from the (Besieged) Pi Sector." In Europejskie Polityki Kulturalne 2015. Raport o Prayszłości Publicznego Finansowania Sztuki Wspótczesnej w Europie. Eds. M. Lind and R. Minichbauer. Warszawa: Bec Zmiana. http:/ / www.wuw-warsaw.pl/raport.php?lang=eng\#JanS.

Sowa, Jan. 2014. "Poza zasada skuteczności.” In Skutecżność sz̧tuki. Ed. T. Załuski. Łódź: Muzeum Sztuki.

Spinelli, Aria. 2018. "Rewriting the History of Art and Activism in Milan. New Forms of Sociality and the Radical Imaginary." Journal for Research Cultures [unpublished manuscript].

Stallabrass, Julian. 2006. High Art Lite: The Rise and Fall of Brit Art. London: Verso.

Standing, Guy. 2014. The Precariat: The New Dangerous Class. London-New York: Bloomsbury.

Steyerl, Hito. 2016. "If You Don't Have Bread, Eat Art!: Contemporary Art and Derivative Fascisms." E-Flux Journal. http://www.e-flux.com/journal/76/69732/if-you-don-thave-bread-eat-art-contemporary-art-and-derivative-fascisms/.

Szadkowski, Krystian. 2015. Uniwersytet jako dobro wspólne: podstawy krytycznych badan nad sækolnictwem wy:şym. Warszawa: Wydawnictwo Naukowe PWN.

Szreder, Kuba. 2013. "Cruel Economy of Authorship.” In Undoing Property? Eds. M. Lewandowska, and L. Ptak. Berlin, New York: Sternberg Press.

Szreder, Kuba. 2015a. "How to Radicalize a Mouse. Notes on Radical Opportunism.” In Mobile Autonomy: Exercises in Artists' Self-Organization. Eds. N. Dockx, and P. Gielen. Amsterdam: Valiz.

Szreder, Kuba. 2015b. "Politicising »independent« Curatorial Practice under Neoliberalism: Critical Responses to the Structural Pressures of Project-Making." [PhD thesis] Loughborough: School of the Arts, Loughborough University.

Szreder, Kuba. 2016. ABC Projektariatu. O nędzy projektowego ṡycia. Warszawa: Bęc Zmiana.

Szreder, Kuba. 2017. "Productive Withdrawals: Art Strikes, Art Worlds, and Art as a Practice of Freedom.” E-Flux Journal December 2017. http:/ / www.e- 
flux.com/journal/87/168899/productive-withdrawals-art-strikes-art-worlds-and-art-asa-practice-of-freedom/.

Universidad Nomada. 2009. "Mental Prototypes and Monster Institutions: Some Notes by Way of an Introduction." In Art and Contemporary Critical Practice: Reinventing Institutional Critique. Eds. G. Raunig, and G. Ray. London: MayFly Books.

Vercellone, Carlo. 2007. "From Formal Subsumption to General Intellect: Elements for a Marxist Reading of the Thesis of Cognitive Capitalism." Historical Materialism 15(1): 1336.

Virno, Paolo. 2004. A Grammar of the Multitude. Los Angeles: Semiotext(e).

Yúdice, George. 2003. The Expediency of Culture : Uses of Culture in the Global Era. DurhamLondon: Duke University Press.

Zukin, Sharon. 1989. Loft Living: Culture and Capital in Urban Change. New York: Rutgers University Press. 
Kuba Szreder - lecturer at the department of art theory at the Academy of Fine Arts in Warsaw. Graduate of sociology at the Jagiellonian University (Krakow), he received PhD from the Loughborough University School of the Arts. He combines his research with independent curatorial practice. In his interdisciplinary projects he carries out artistic and organizational experiments, hybridizing art with other domains of life. In 2009 he initiated Free / Slow University of Warsaw, with which he completed several inquiries into the political economy of contemporary artistic production, such as Joy Forever. Political Economy of Social Creativity (2011) and Art Factory. Division of labor and distribution of resources in the field of contemporary art in Poland (2014). Editor and author of several catalogues, readers, book chapters and articles. In his most recent book $A B C$ of Projectariat (Polish edition, 2016), he scrutinizes economic and governmental aspects of project-related modes of artistic production.

\section{ADRESS:}

The Department for Visual Culture

Academy of Fine Arts in Warsaw

Wybrzeże Kościuszkowskie 37/39

00-379 Warszawa

E-MAIL: derszer@gmail.com

CITATION: Szreder, Kuba. 2018. "Instituting the Common in Practices of Artistic Circulation: From Entrepreneurship of the Self to Entrepreneurship of the Multitude." Praktyka Teoretyczna 1(27): 193-223.

DOI: $10.14746 /$ prt.2018.1.8

Kuba Szreder - wykładowca w Katedrze Teorii Kultury Akademii Sztuk Pięknych w Warszawie. Absolwent socjologii na Uniwersytecie Jagiellońskim, doktorat obronił na Loughborough University School of the Arts. Swoje badania łączy z praktyką niezależnego kuratora. W ramach swoich interdyscyplinarnych projektów przeprowadza artystyczne i organizacyjne eksperymenty, hybrydyzujące sztukę i inne dziedziny życia. W 2009 roku zainicjował powstanie Wolnego Uniwersytetu Warszawy, wraz z którym przeprowadził szereg badań dotyczących związków ekonomii politycznej i współczesnej produkcji artystycznej. Efektem tych prac są między innymi tomy: Wieczna radość. Ekonomia polityczna społecznej kreatywności (2011), Fabryka sztuki. Podział pracy oraz dystrybucja kapitałów społecznych w polu sztuk wizualnych we współczesnej Polsce (2014). Redaktor i autor wielu katalogów, przewodników, rozdziałów i artykułów. W swojej ostatniej książce, ABC Projektariatu (2016), analizuje ekonomiczne i publiczne aspekty form artystycznej produkcji związanych z projektami. 
TYTUL: Instytucje dóbr wspólnych w artystycznej cyrkulacji: od przedsiębiorców siebie do przedsiębiorczości wielości.

ABSTRAKT: Autor analizuje sprzeczności charakterystyczne dla globalnego obiegu sztuki, który ujmowany jest dialektycznie, jako system eksploatacji oraz miejsce potencjalnego wytwarzania instytucji dóbr wspólnych. Analiza przeprowadzona została w duchu metodologicznej syntezy dialektycznego materializmu, socjologii sztuki i badań w działaniu. Teoretyczny namysł nad strukturalnymi determinantami autor łączy z czujną obserwacją praktyk, które wyłaniają się w krytycznej reakcji na systemy eksploatacji. Opierając swoją analizę na empirycznych przykładach, wskazuje on na polityczny wymiar społecznych konfliktów, które wyłaniają się w toku ekstrakcji wartości z rozproszonej pracy artystycznej cyrkulacji. Szreder argumentuje, że takie konflikty często są wykorzystywane przez progresywnych robotników sztuki do politycznej mobilizacji. Tym samym przedstawia nowe spojrzenie na obecną inkorporacje produkcji artystycznej w cykle akumulacji kapitału i formy podtrzymywania społecznej dystynkcji, specyficzne dla późnego kapitalizmu. W artykule wysunięta zostaje teza, że zamiast opłakiwać utratę artystycznej autonomii, należy zmieniać społeczne aparaty regulujące artystyczną cyrkulację na rzecz pracowników i pracowniczek artystycznego obiegu.

SLOWA KLUCZOWE: obieg sztuki, konflikt społeczny, dobra wspólne, przedsiębiorcy siebie, strukturalny oportunizm, robotnicy sztuki. 